\title{
Do fruit morphology and scarification affect germination and predation rates of Babassu seeds?
}

\author{
Paulo Henrique Gonçalves Ferreira', Yule Roberta Ferreira Nunes', Maurício Lopes Faria', Murilo Malveira \\ Brandão', Cibele Stramare Ribeiro Costa², Henrique Maia Valério', Geraldo Aclécio Melo' and Marcio Antonio Silva \\ Pimenta $^{*}$
}

Received: June 29, 2016

Accepted: November 10, 2016

\begin{abstract}
Seed predation is a natural phenomenon that can occur either before or after dispersal and can significantly reduce the economic value and reproductive potential of plants. The babassu palm (Attalea vitrivir, Arecaceae) is important to rural communities that extract oil from its fruits for a wide variety of uses. We evaluated the predation and germination of A. vitrivirseeds in Pandeiros River Environmental Protection Area (EPA-Pandeiros) in Minas Gerais State, Brazil. Sixty individual plants were evaluated to determine their fruiting patterns. Seed predation and germination were evaluated in the natural environment for eight months for fruits divided into two treatments: scarified and intact. Germination of fruits submitted to these same treatments was also evaluated under greenhouse conditions. Our results indicated that fruiting is continuous in this species and that fruit morphology does not influence either germination or predation. Likewise, fruit scarification did not influence seed germination. Pachymerus cardo (Coleoptera: Chrysomelidae) preferentially oviposited on scarified fruits, but only after their dispersal. The predation rate in the natural environment was $14.6 \%$. Germination was not observed under natural conditions, but reached $33.05 \%$ under greenhouse conditions.
\end{abstract}

Keywords: Arecaceae, Attalea vitrivir, Babassu palm, fruit, seed germination, seed predation

\section{Introduction}

Babassu palms belong to the genus Attalea, although prior to 2008 they were classified into four different genera: Orbignya, Maximiliana, Scheelea, and Attalea (Lorenzi et al. 2010). The species Attalea vitrivir is restricted to northwestern Minas Gerais State and southern Bahia State, Brazil (Lorenzi et al. 2010) and produce up to 15 million tons of fruit per year (Costa \& Marchi 2008). The seeds have a high oil content, which can be extracted for use in the cosmetic and food industries and to make detergents and lubricants. Babassu palms have significant socioeconomic importance because the products derived from them are widely used by populations that rely on subsistence agriculture (Lima et al. 2007), and so studies examining their fruiting patterns could significantly aid in the use and conservation of this resource.

The periods and durations of fruiting vary among the different species of Attalea, and can occur continuously or discontinuously throughout the year or in alternate years (Fisch et al. 2000; Martini et al. 2011). In their study of Attalea speciosa (synonym Orbignya phalerata), Araújo et al. (1996) noted that the species produces fruits constantly, although not all of the plants within a given population were

\footnotetext{
${ }^{1}$ Departamento de Biologia Geral, Universidade Estadual de Montes Claros,Campus Darcy Ribeiro, Vila Mauricéia, 39401-089, Montes Claros, MG, Brazil

${ }^{2}$ Departamento de Zoologia, Universidade Federal do Paraná,P.O. Box 19020, 81531-980 Curitiba, PR, Brazil
}

${ }^{*}$ Corresponding author: marcio.pimenta@unimontes.br 
found to be fruiting simultaneously during the study period.

Information about seed germination is important for understanding the reproductive strategy of a species and its population dynamics (Alencar et al. 2012). Various biotic and abiotic factors can havean influence on seed germination rates. Abiotic factors include, among others, water and oxygen availability, as well as temperature and other climatic conditions necessary for a particular species (Panza et al. 2007). Biotic factors include seed resistance to desiccation, the presence or absence of dormancy (Vasconcelos et al. 2011), fruit morphology, and seed predation (Sari \& RibeiroCosta 2005). Viable seeds will not germinate even though all of the necessary environmental conditions have been met, a phenomenon known as seed dormancy (Anselmini et al. 2010). Dormancy results in temporal delays in the germination process, and can aid the dispersal of seeds over greater geographic distances (Kaye et al.1997). Similarly, dormancy can maximize seedling survival by avoiding germination under unfavorable conditions (Vasconcelos et al. 2011).

Fruits of palm trees belonging to the genus Attalea (such as Attalea speciosa; synonym Orbignya phalerata) contain seeds with rich energy sources (Costa \& Marchi 2008) that attract many animal predators, especially those that feed on the endosperm (Guix 2006). Seed predation is a natural phenomenon that can result in significant reductions of the reproductive potentials of host plants (Kolb et al. 2007). In some cases, predation by insects and vertebrates can eliminate $100 \%$ of the seeds produced during a reproductive cycle (Francisco et al. 2003), affecting not only the population dynamics of those plants but the structure of the entire community (Ramirez \& Traveset 2010).

Among the important insect predators of seeds, the subfamily Bruchinae of the Chrysomelidae (Coleoptera) comprise species with very homogeneous diets, with the larva that feed on seeds of plants from 33 families, with more than $80 \%$ of the host plants belonging to the family Fabaceae (=Leguminosae) (Johnson et al. 1995). However, many show high specificity for certain plants (Janzen 1980), or what is termed taxonomic conservatism in host-plant use. Pachymerus nucleorum and Pachymerus cardo, both belong to the Chrysomelidae, subfamily Bruchinae, tribe Pachymerini (Grenha et al. 2008). According to Johnson et al. (1995), species of the tribe Pachymerini feed almost exclusively on palm seeds, and are commonly known as palm-beetles. Castro \& Roldan (2001) demonstrated the presence of these two species of insects (P. nucleorum and P. cardo) on palms of the genus Attalea, although no mention was found in the literature about these insects attacking $A$. vitrivir seeds.

In some species of palms, seed predation can occur either before or after dispersal (Kolb et al. 2007). The palms Attalea maripa (Guix 2006), Attalea phalerata (Castro \& Roldan 2001), Acrocomia aculeate (Scariot 1998), and Syagrus oleracea (Garcia et al. 1980) all grow to heights of more than $10 \mathrm{~m}$, and seed predation has only been observed after dispersal. The palms Allagoptera arenaria (Grenha et al. 2008) and Bactris acanthocarpa (Silva \& Tabarelli 2001), however, produce bunches of fruits that are held very close to the ground and are predated on by the same beetles both before and after dispersal, suggesting that plant height influences predation.

Characterization of seed predation and germination are of significant importance because they are closely related to the reproductive success of plants, since seed predators depreciate the endosperm and/or embryo (Alencar et al. 2012). Remaining populations of babassu palm are found in impacted areas, such as pastures, small gallery forests and savannas fragments in north and northwestern Minas Gerais and southern Bahia, Brazil (Lorenzi et al. 2010). In these populations, seeds of $A$. vitrivir, which have not been predated, are exploited for the extraction of the oil for food, the cosmetics industry, and the fabrication of detergents and lubricants. The irrational exploitation of seeds and the natural predation of fruits may prevent natural regeneration of these palms and influence gene flow among populations through seeds. In this regard, understanding the fructification, dispersal and seed predation of $A$. vitrivir is important for guiding management and conservation programs for the species, and especially for the production of seedlings. As such, the present work addressed the following questions: (I) What is the fruiting period of A.vitrivir?; (II) Which insect species are predators of $A$. vitrivir seeds?; (III) Does predation occurr before and/or after dispersal?; (IV) Does fruit morphology or fruit scarification affect the rates of germination and/or seed predation of A. vitrivir?; and, (V) What are the implications of the fruiting pattern of this species for predation rates?

\section{Materials and methods}

\section{Study species}

Nine palm species belonging to the genus Attalea (Humboldt) can be encountered in Minas Gerais State, Brazil (Lorenzi et al. 2010). Attalea vitrivir Zona (synonym Orbignya oleifera Burret), the focus of the present study, is found in northern Minas Gerais and in southwestern Bahia, where it occurs in pasture areas previously occupied by gallery forest and cerrado (neotropical savanna) vegetation (Lorenzi et al. 2010). Attalea vitrivir Zona has a simple trunk that can reach $20 \mathrm{~m}$ in height; its leaves are approximately 8 $\mathrm{m}$ long, with $156-206$ pairs of uniformly distributed pinnate leaflets; the leaves themselves are held generally upright in the form of a cup (Lorenzi et al. 1996).

The fruits of A. vitrivir are elliptic, more or less cylindrical and weigh between 45 and $287 \mathrm{~g}$. They possess a fibrous epicarp, a farinaceous mesocarp ( 0.57 to $3.25 \mathrm{~mm}$ thick), and a hard endocarp, and hold from two to nine seeds that are from 1.4 to $5.8 \mathrm{~cm}$ long and from 0.74 to $2.20 \mathrm{~cm}$ wide 
(Guedes et al. 2015). Fruits are considered mature when they take on a brownish color and can be easily removed from bunches.

\section{Study area}

Fruits of $A$. vitrivir were collected from two areas within the Pandeiros River Environmental Protection Area (EPA - Pandeiros), which is located in the municipalities of Januária, Cônego Marinho, and Bonito de Minas, in northern Minas Gerais, Brazil (Nunes et al. 2009). Area 1 ( $\left.15^{\circ} 27^{\prime} 06^{\prime \prime} S, 44^{\circ} 41^{\prime} 44^{\prime \prime} \mathrm{W}\right)$ and Area 2 (15 $28^{\prime} 39^{\prime \prime} S$, $44^{\circ} 46^{\prime} 20^{\prime \prime} \mathrm{W}$ ) are located $10 \mathrm{Km}$ apart in the municipality

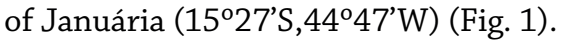

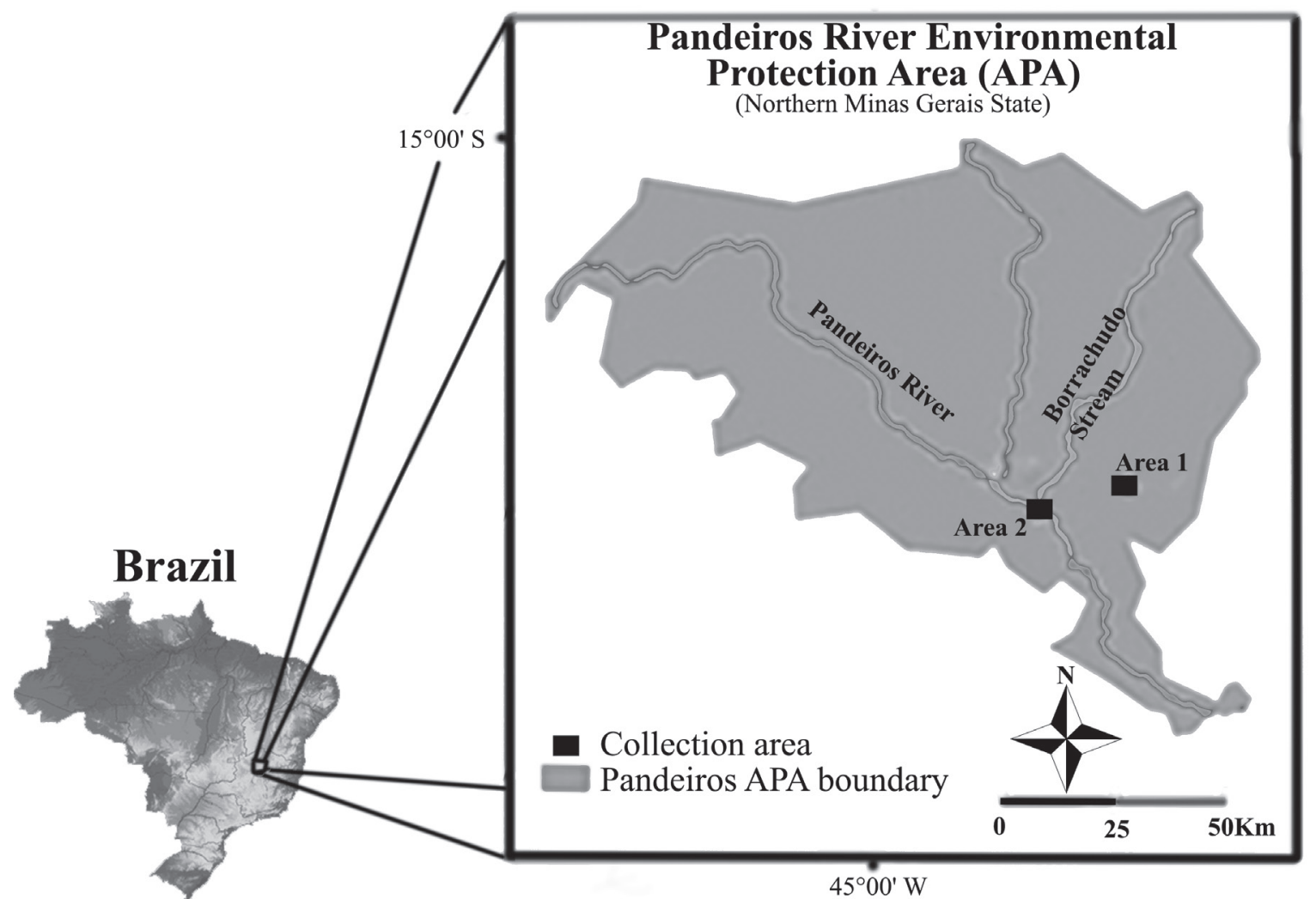

Figure 1. Location of the River Pandeiros Environmental Protection Area (EPA) in Minas Gerais State, Brazil, with schematic representations of the two sampling areas (Januária, northern Minas Gerais State).

The EPA - Pandeiros was created by State Law 11.901 in 01/09/1995, and encompasses 393,060 ha with a variety of phytophysiognomies, including cerrado sensu stricto, dry forests (Seasonal Dry Tropical Forests - SDTFs), gallery forests, grasslands, and seasonally flooded plains (Nunes et al. 2009; Matos et al. 2014). The soils of the Pandeiros River basin are essentially sandy, unstructured, deep, and well-drained (IGA 2006). The regional climate is tropical humid (Aw, according to the Köppen classification), with well-defined rainy and dry seasons (Antunes 1994); mean annual temperatures vary from 21 to $24^{\circ} \mathrm{C}$, and mean annual rain fall varies from 900 to $1200 \mathrm{~mm}$ (INMET 2012).

Two well-defined seasons were observed in 2011 (INMET2012), with rainfall concentrated from October to March (accumulated rainfall approximately $760 \mathrm{~mm}$ ) and a dry season between April and September (with approximately $65 \mathrm{~mm}$ of rainfall).

\section{Determination of the fruiting period}

To determine the fruiting period of $A$. vitrivir, we observed 60 reproductively mature adult plants marked within the study area. As A. vitrivir fruits do not lose the floral parts of the female inflorescences under natural conditions, the expansion of the ovary was considered an increase in the radius of the flowers. Field observations of fruiting phenophases (just observing the presence or absence of a phenophase) were made monthly between June/2009 and September/2010, and recorded the presence of fruit bunches in different stages of maturity (green, mature, or without fruits) and the number of bunches on each plant. 
Determination of predation during pre- and postdispersal in natural conditions

To quantify predation after dispersal under natural conditions, we collected 300 mature fruits of A. vitrivir in their pre-dispersal phase in the two distinct sampling areas (Areas 1 and 2); 150 fruits from five individuals approximately $8 \mathrm{~m}$ tall in each area. Subsequently, 75 of the fruits from each area were placed directly on the ground below the palms from which the fruits were harvested in Area 1(total of 150 fruits) and left for three months.

After the three-month period, the 150 fruits were gathered and take to the Conservation Genetics Laboratory (LabGene) of the Unimontes University in Montes Claros where they were opened by way of a transversal incision using an electrical circular saw fitted with a diamond composite blade(due to the extremely rigid endocarp) (Guedes et al. 2015). The occurrence of seed predation in the fruit was defined as the presence of larvae, pupae, and/ or adult insects in the cavity of the endocarp where the seeds are located, or by the presence of exit orifices made by adult insects.

To determine fruit predation before dispersal, 75 recently harvested fruits from each sampling area were immediately brought to the laboratory and assessed for predation using the criteria and methodology described above. Additionally, to examine possible predation of fruit bunches held below $8 \mathrm{~m}$, another 90 fruits were collected from three palms ( 30 fruits from each tree) containing mature bunches held only $2 \mathrm{~m}$ above the ground. These bunches were likewise removed to the laboratory for assessment as described above.

\section{The influence of fruit morphology and scarification on germination under greenhouse conditions}

To determine if fruit biometrics have any influence on the germination rates of $A$. vitrivir under greenhouse conditions, 360 mature fruits were collected from 12 palm trees in Area 1 (30 fruits per palm) and taken to the laboratory where their lengths and widths $(\mathrm{cm})$ were measured. Of those 30 fruits from each palm, 15 were scarified using the methodology described above to the depth of the endocarp on the extremity of the fruit (where the petiole would emerge) and 15 were maintained intact as controls. This manual scarification of the fruits was performed to simulate natural scarification by rodents, as described by Silvius \& Fragoso (2002) for A. maripa (Aubl.) Mart., and the scarification of A. vitrivir fruits by invertebrates (personal observations). All of the fruits were planted individually in August/2011 in 5 L polyethylene planting sacks containing washed sand. The sacks were then placed in the Experimental Biology greenhouse on the UNIMONTES campus (Montes Claros) and irrigated twice-daily (to simulate environmental conditions during the rainy season). The number of germinating fruits was recorded during the subsequent five months (August/2011 to January/2012), after which the fruits were opened to count the number of germinating seeds. Seeds were considered to have germinated if their primary leaf had emerged.

\section{The influence of fruit morphology and scarification on predation and germination in natural conditions}

To characterize the rates of predation and germination under natural environment conditions we randomly harvested 800 mature fruits from 10 palm trees prior to dispersal (in Area 1, in April/2011). After harvesting, 400 of the fruits were scarified (using the methodology described above), while the other 400 fruits were left intact.

Three days after harvesting, the scarified and intact fruits were left on the ground in Area 1 under 10 reproductively mature palm trees but were kept within 40 iron cages (four beneath each palm) covered with a fine steel mesh. Each cage contained 20 fruits, 10 scarified and 10 intact. To efficiently occupy the greatest possible area under each palm tree, the four cages beneath each palm tree were located $1.5 \mathrm{~m}$ from the trunk in North, South, East, and West directions. The cages were used to impede fruit removal by rodents.

Every two months (June, August, October, and December/2011, for a total of eight months of exposure), one randomly chosen cage from beneath each palm tree was removed, for a total of 10 cages and 200 fruits per observation period. The 10 scarified and 10 intact fruits of each cage were examined for germination and then removed and placed in black polyethylene sacks for transport.

Each bimonthly lot of fruits was taken to the laboratory where individual fruits were placed in plastic pots with small holes to facilitate air circulation. Before opening the fruits to inspect them for signs of predation, they were measured (length and width). The number of intact seeds, and those that had experienced predation, were tallied. To identify predatory insects, any adults encountered were removed, stored in $70 \%$ alcohol, and sent for identification to the Coleoptera Systematics and Bioecology Laboratory of the Federal University of Paraná (UFPR).

\section{Data analyses}

An activity index was used to record fruiting phenofase, following Bencke \& Morellato (2002). The activity index (or percentage of individuals) it is a simple method that only uses the presence or absence of a phenophase for an individual, and does not estimate intensity or quantity.

Generalized linear models (GLM) were used to characterize germination and predation under natural conditions, utilizing the distribution of binomial errors, using $\mathrm{R}_{(2.13 .0)}$ software (R Development Core Team 2011). 
A single fruit was considered a sampling unit. The same software program was used to evaluate greenhouse germination by analyzing survival. The effects of the biometric variables (width, length, and number of seeds per fruit) were evaluated using the chi-square test.

\section{Results}

\section{Determination of the fruiting period}

Continuous production of fruits was observed for $A$. vitrivir, resulting in the presence of mature fruits during the entire period of phenological evaluation (16 months). The fruiting activity index for 60 plants varied from 81.8 to $88.3 \%$ during the evaluation period (Fig. 2).

Fruit bunches in different stages of maturation were encountered on the palms, as well as the coexistence of bunches at different stages of maturation (green, mature, brownish bunches) on the same individual; palms without fruits were always observed - thus continuous fruit production was observed in the $A$. vitrivir population, although not all individuals were producing fruit at any given time. The number of fruit bunches varied among individuals, with some palms bearing up to nine bunches simultaneously.

\section{The influence of fruit morphology and scarification on germination under greenhouse conditions}

Fruits held to germinate under greenhouse conditions at the beginning of August exhibited germination after the 11 th week, and continuing on to the 24 th week. Of the 360 fruits sown for germination, 119 (33.05 \%) germinated. The fruits that germinated were found to contain a total of 1809 seeds, and 280 (15.45\%) of those seeds had germinated. The period of greatest germination (nearly half of the total germinated) occurred between the 16 th and 17 th week (110 to 115 days) under both treatments (scarified/intact).

Survival analyses demonstrated that there were no significant differences between the germination rates of scarified and intact fruits (mean $76 \pm 3.4$, p > 0.05). Likewise, there were no significant relationships between germination and the biometric variables analyzed (width, length, weight, and numbers of seeds per fruit).

\section{The influence of fruit morphology and scarification on predation and germination in natural conditions}

None of the fruits collected in the pre-dispersal phase, whether in bunches at $8 \mathrm{~m}$ or $2 \mathrm{~m}$ above the ground, exhibited seed predation, however, fruits left on the ground in the field (post-dispersal), did. The insect predator found in A. vitrivir fruits was identified as the bruchine Pachymerus cardo (Coleoptera, Chrysomelidae).

Of the 800 fruits left exposed on the ground in the field, 117 (14.6\%) showed signs of predation. Each fruit could contain more than one seed, with the number of seeds varying from 1 to 9 seeds/fruit. Seed predation was less frequent than fruit predation, with only 154 (4.17\%) of the total 3685 seeds removed from the fruits exhibiting predation by $P$. cardo. The predation rates of the collections made every two months did not demonstrate statistically significant differences among themselves $(p=0.92)($ Tab. 1$)$. There were no statistically significant differences between the observed and expected numbers of fruits demonstrating

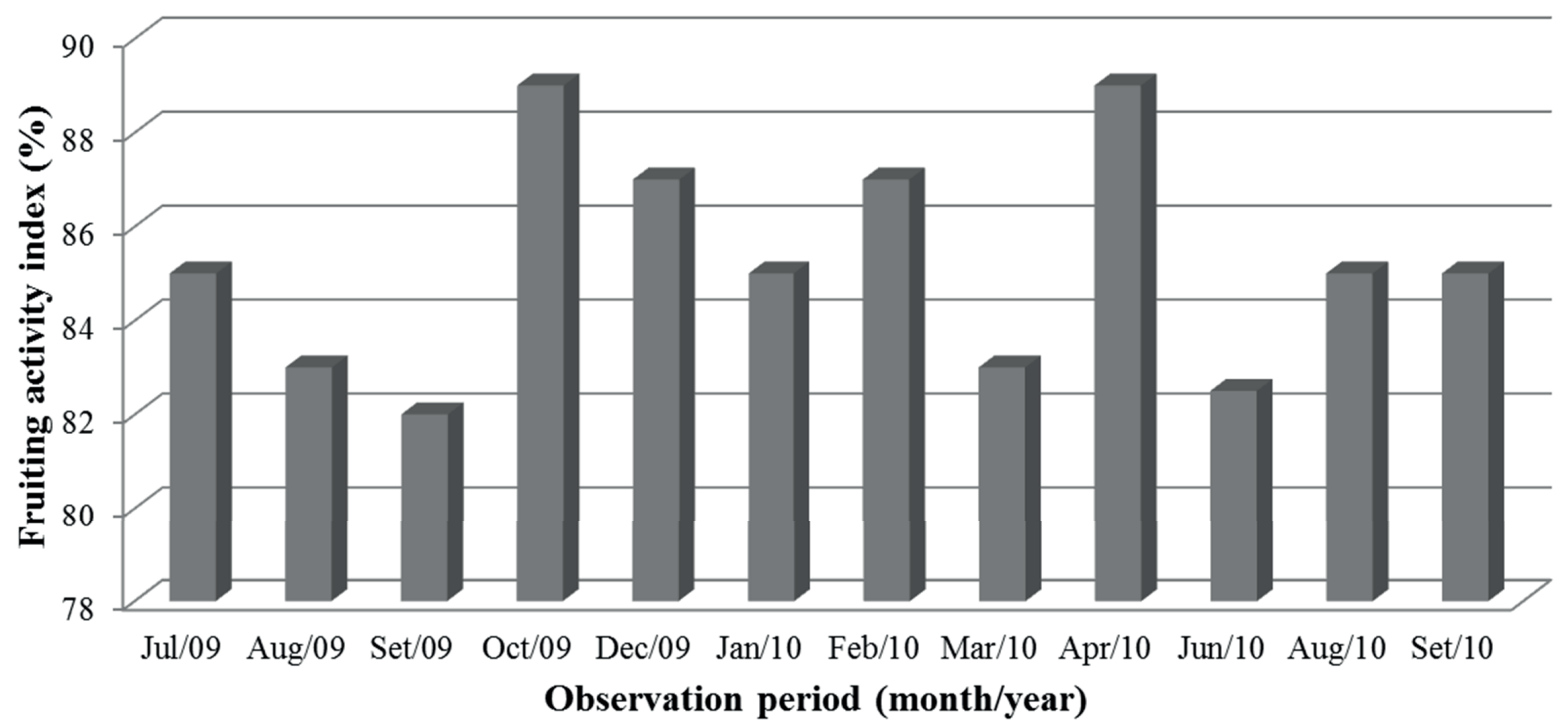

Figure 2. Fruiting activity index of 60 individual plants of Attalea vitrivir Zona (Arecaceae) during 16 months, growing in the EPAPandeiros (Januária, Minas Gerais). 
by P.cardo and P. nucleorum, respectively, in both pre-and post-dispersal conditions.
After initial barochoric dispersal, A. vitrivir fruits can be scarified and dispersed by rodents such as the agouti

Table 1. Number of fruits and seeds of Attalea vitrivir Zona (Arecaceae) and the number of diaspores showing predation after exposure on the ground in a natural environment for eight months in the EPA-Rio Pandeiros, Januária, MG, Brazil.

\begin{tabular}{|l|c|c|c|c|c|}
\hline \multirow{2}{*}{ Item } & \multicolumn{5}{|c|}{ Exposure period (months) } \\
\cline { 2 - 6 } & $\mathbf{2}$ & $\mathbf{4}$ & $\mathbf{6}$ & $\mathbf{8}$ & \multicolumn{1}{c|}{ Total } \\
\hline Fruits & 200 & 200 & 200 & 800 \\
\hline Fruit predation* & $29(14.5 \%)$ & $31(15.5 \%)$ & $23(11.5 \%)$ & $34(17 \%)$ & $117(14.6 \%)$ \\
\hline Seeds & 908 & 935 & 935 & 917 & 3685 \\
\hline Seed predation* & 39 & 42 & 29 & 44 & 154 \\
\hline P. cardo larva & 15 & 18 & 19 & 40 & 92 \\
\hline P. cardo adults & 15 & 18 & 7 & 3 & 45 \\
\hline Pupa & 7 & 6 & 3 & 1 & 17 \\
\hline
\end{tabular}

(\%): Predation percentage in the period.

$\left.{ }^{*}\right): \alpha=2.58$; Deviance $=0.0122, \mathrm{p}=0.92$

predation in relation to the variables of fruit width (n obs.= $117 ; \mathrm{n}$ exp.=113 D.f. $5 ; \chi 2=4.694 ; \mathrm{p}=0.454)$ and length ( $\mathrm{n}$ obs. $=113 ; \mathrm{n}$ exp. $=114$ D.f. $5 ; \chi 2=3.170 ; \mathrm{p}=0.673$ ) (Fig. 3A, B).

Seed predation was not correlated with the number of seeds per fruit. The scarification and intact treatments, on the other hand, indicated a preference by female $P$. cardo for ovipositing on scarified fruits $(58.12 \%, \pm 3.336, \mathrm{p}=0.02)$.

None of the fruits experienced $100 \%$ seed predation. Only one adult insect, or one larva in its final instar stage, was encountered in any single seed that exhibited evidence of predation. Predatory insects ( $P$. cardo) in more than one development stage were encountered in the same fruit.

None of the fruits held under natural conditions germinated during the eight months of exposure. When germination evaluations were concluded after the fourth collection, the 200 fruits of this last collection were taken to the laboratory and held in black polyethylene sacks for 20 days. After the 20 days, germination was observed in 74 scarified fruits (37\%) and 78 intact fruits (39\%), for a total of152 germinated fruits (76\%). After opening the fruits, of the 905 seeds present, 472 (52.15\%) had germinated; none of the damage or totally consumed seeds had germinated.

\section{Discussion}

Jardim\& Kageyama (1994) and Fisch et al. (2000) reported continuous fruiting in populations of the palms Euterpe oleracea and E. edulis, although with alternating fruiting among the separate individuals evaluated. These results are similar to those of the present study with $A$. vitrivir, which demonstrated continuous fruiting during 16 months, with fruiting alternating among different individuals. This pattern is not, however, standard among palm trees, as Storti (1993) described fruiting in the buriti palm (Mauritia flexuosa) to occur every two years and lasting for more than 12 months.

The fruiting phenophase is associated with plant-animal interactions of dispersal and seed predation (Jardim \& Kageyama 1994). The continuous fruiting of $A$. vitrivir guarantees an abundance of available fruits on the ground during the entire year, which could explain the fact that insects oviposited only on post-dispersal fruits. The fact that most adult plants produce fruit bunches approximately 8 $\mathrm{m}$ above the ground may also be a factor in explaining the pattern of post-dispersal predation by $P$. cardo, as that same insect is known to act as a predator on Bactris acanthocarpa palm fruits in their pre-dispersal phase (Silva \& Tabarelli 2001), although those fruits are held just a few centimeters above the ground.

In spite of the fact that fruiting was continuous in $A$. vitrivir, germination under natural conditions was not observed in the field for up to eight months after sowing. These results corroborated those reported by Lorenzi et al. (2010), who estimated that this species would require from 6 to 8 months to germinate in the field. Neves et al. (2013) and Simão et al. (2013) stressed the importance of abiotic effects on palm germination, especially temperature (Labouriau \& Agudo 1987) and humidity. Neves et al. (2013) found that $A$. vitrivir seeds that did not attain $25 \%$ humidity did not germinate. This corroborates the observation of rapid germination of $A$. vitrivir under greenhouse conditions when the fruits were watered daily (with germination initiating at approximately the third month). This dependence on humidity was also apparent under natural conditions, as rainfall during the test period was low $(65 \mathrm{~mm})$, and increased significantly $(440 \mathrm{~mm})$ only very close to the end of the experiment. As such, it is possible that the fruits from the fourth and final test group would have demonstrated germination if they had been left exposed in the field (as the seeds taken to the laboratory were found to be viable and subsequently successfully germinated). 
Paulo Henrique Gonçalves Ferreira, Yule Roberta Ferreira Nunes, Maurício Lopes Faria, Murilo Malveira Brandão, Cibele Stramare Ribeiro Costa, Henrique Maia Valério, Geraldo Aclécio Melo and Marcio Antonio Silva Pimenta
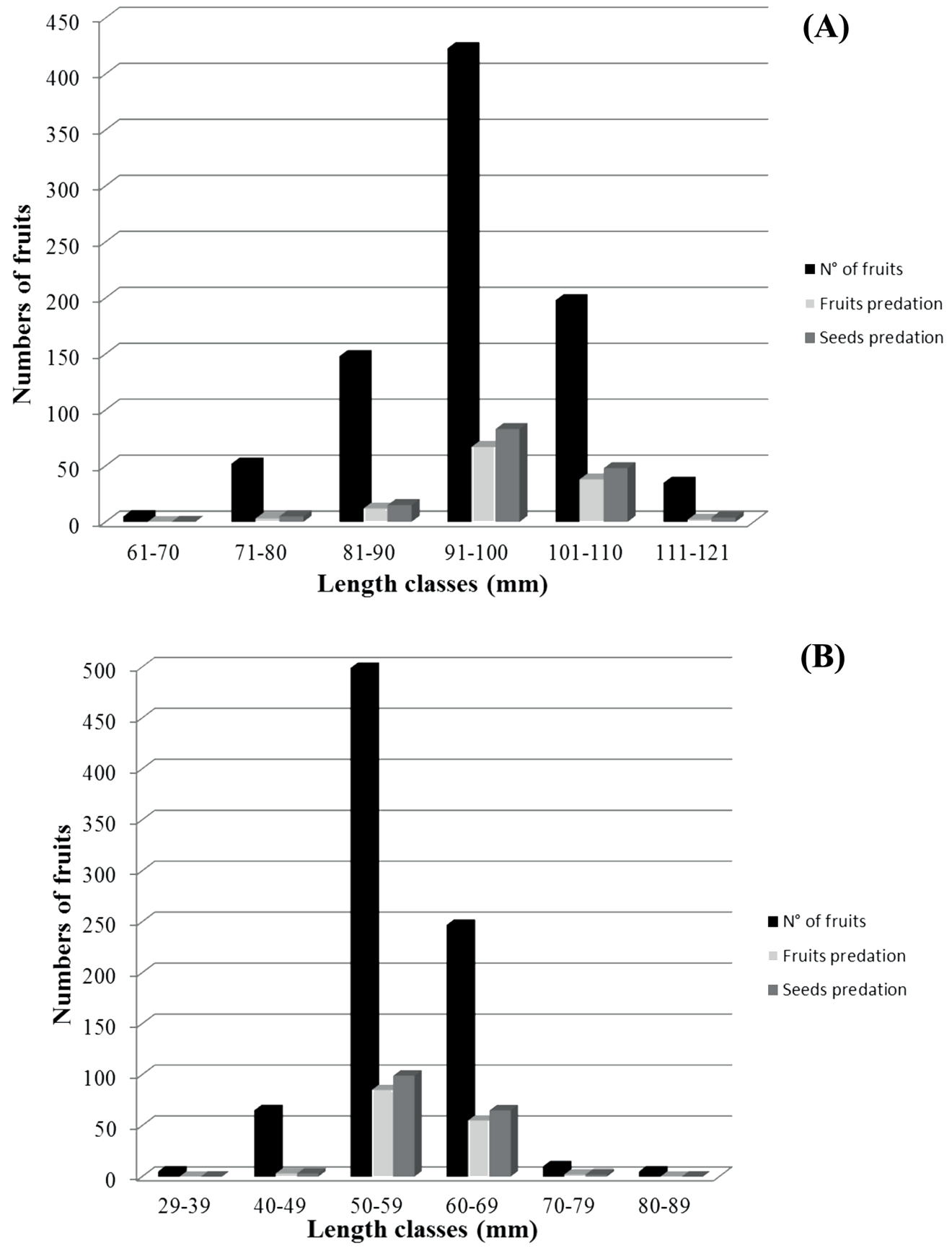

Figure 3. (A) Relationships between the length and (B) width of A. vitrivir fruits and seed predation by P. cardo.

In relation to fruit morphology and germination rates, Lin (1988) reported that the largest heart palm fruits (E. edulis) demonstrated the highest germination rates. The germination rates of $A$. vitrivir fruits, however, did not demonstrate any relationship with fruit size or size class. Likewise, $P$. cardo females did not show any preference/bias for fruit size in terms of their predation rates. A. vitrivir fruits did not demonstrate any significant differences in germination rates between scarified and intact fruits.

Seed predation in palms can occur either before or after dispersal (Kolb et al. 2007), and can be influenced by plant height (Silva \& Tabarelli 2001). Predation by P. cardo on $A$. maripa and $A$. phalerata palms, both with heights of approximately $20 \mathrm{~m}$, occurs only after dispersal (Castro \& Roldan 2001; Guix 2006). Acrocomia aculleata, A. speciosa, and Syagrus oleracea, which grow up to $10 \mathrm{~m}$ in height, likewise demonstrated seed predation by $P$. nucleurum (a congeneric species) only in the post-dispersal phase (Garcia et al. 1980; Scariot 1998). However, Silvius \& Fragoso (2002) and Grenha et al. (2008) reported seed predation in the shorter palms (approximately $2 \mathrm{~m}$ tall) Bactris acanthocarpa and Allagoptera arenaria (Arecaceae) 
(Dasyprocta spp.; Dasyproctidae) (Guix 2006). Silvius \& Fragoso (2002) reported that the predation of A. maripa seeds by $P$. cardo was more severe when the fruit epicarps and mesocarps had been partially removed. Janzen (1971) noted that the seed beetle, probably Speciomerus giganteus, would not oviposit on $A$. butyracea if the fruitpulp had not been previously moved by vertebrates or fungal growth. A similar situation was observed in the present study among fruits maintained in the field, with P. cardo demonstrating a preference for scarified fruits for ovipositing. Scarification probably facilitates the entrance of $P$. cardo larva.

Studies of plants of the family Fabaceae indicated that fruit vigor, as reflected in their length, thickness, width, and weight, appeared to be related to higher levels of predation, probably because larger fruits have larger quantities of available resources (seeds) and are thus targeted by predators (Souza et al. 2007). The present study, however, revealed no ovipositing preference by $P$. cardo in relation to fruit size (length and width), so that fruit predation was highest in the most abundant size classes. Additionally, the wide variation observed in the number of seeds per fruit (corroborating the findings of Guedes et al. (2015)) who reported that the number of seeds per fruit in $A$. vitrivir was not normally distributed) maybe responsible for the lack of any observable preference for ovipositing on a specific fruit class size by P. cardo, since even large fruits can contain variable numbers of seeds.

In relation to temporal variation in predation rates, Janzen (1971) noted that the probability of a seed being infested would increase as the time of fruit exposure to female insects increased. The predation rate of $P$. cardo on $A$. vitrivir fruits, however, indicated that ovipositing occurred only during the first months after dispersal, which may be related to the capacity of insects to perceive newly fallen fruits for only limited periods of time. One explanation for this would be that the insects use volatile compounds to locate fruits, and the release of those chemicals by severed fruits would diminish over time. This was demonstrated by Narain \& Bora (1992), who found a decrease in volatile compound release by fruits of Passiflora edulis F. flavicarpa over time after dispersal. Additionally, the continuous production of $A$. vitrivir fruits guarantee stocks of new fruits (mature and intact) on the ground throughout the year, so that if $P$. cardo females had a preference for ovipositing only on recently dispersed fruits they could do so continually. Similar results were reported by Grenha et al. (2008) for Allagoptera arenaria (Arecaceae), where the continuous production of fruits, even with fruiting peaks, did not generate variation in predation rates by $P$. nucleorum.

In spite of the low predation rate observed in A. vitrivir, it is important to note that this study was undertaken only during the dry season. As such, it is possible that there is, in fact, seasonal variation in predation as was reported by Silvius \& Fragoso (2002), who observed the predation rate of $P$. cardo on A. maripa to vary from 60 to
$94 \%$, during the dry and rainy seasons, respectively. Attalea phalerata fruits exposed for eight months, including the rainy season, demonstrated $60 \%$ predation by $P$. cardo (Castro \& Roldan 2001), although A. arenaria, which also demonstrated continuous fruiting, suffered $20.6 \%$ predation by P. nucleurum (Grenha et al. 2008).

Seed predation by P. cardo diminished the number of viable seeds dispersed during the dry season that could otherwise have germinated under favorable natural conditions. It is important to remember, however, that A. vitrivir fruits normally contain more than one seed and no fruits were found with $100 \%$ seed predation. As such, even fruits that have suffered predation are still capable of germination. Neves et al. (2013) suggested that abiotic factors such as temperature and humidity act together to influence germination in A. vitrivir - so that additional future studies will be needed to evaluate predation and germination in different seasons.

In summary, our results demonstrated that fruiting in Attalea vitrivir is continuous. The insect predator encountered in A. vitrivir fruits was identified as Pachymerus cardo (Coleoptera, Chrysomelidae, Bruchinae, Pachymerini), with seed predation occurring only after fruit dispersal. Neither fruit morphology nor scarification influenced germination rates. Insects demonstrated a preference for scarified fruits for ovipositing, but fruit morphology did not affect their predation. We were able to determine that ovipositing occurs only during the first months after fruit dispersal, probably in response to the continuous production of $A$. vitrivir fruits (which guarantees renewed stocks of fruits [mature and intact] on the ground during the entire year).

\section{Acknowledgments}

We thank FAPEMIG (Fundação de Amparo à Pesquisa do Estado de Minas Gerais) for the financial support given to Marcio Antonio Silva Pimenta (Process: CBBAPQ-01552-08), for the BIPDT grants awarded to M.A.S. Pimenta and H.M. Valério, for the Researcher Visiting grant (RVF) granted to M.M. Brandão; as well as the Universidade Estadual de Montes Claros - UNIMONTES and the Instituto Estadual de Florestas - IEF/MG for their logistic support.

\section{References}

Alencar NLM, Filho EG, Innecco R. 2012. Note Cereus jamacaru seed germination and initial seedling establishment as a function of light and temperature conditions. Scientia Agricola 69: 70-74.

Anselmini JI, Deschamps C, Gavazza MIA, Zanette F, Panobianco M. 2010. Dormência e germinação de sementes de Melaleuca alternifolia Cheel. Revista Brasileira Plantas Medicinais 12: 149-152.

Antunes F Z. 1994. Caracterização climática. Informe Agropecuário, Belo Horizonte/MG, 17: 15-19.

Araújo ECE, Mendes AMC, Ribeiro FE. 1996. Comportamento fenológico do babaçu (Orbignya phalerata) em três tipos de solos do Piauí. Teresina, EMBRAPA CPAMN. Boletim de Pesquisa 15. 
Bencke CSC, Morellato LPC. 2002. Comparação de dois métodos de avaliação da fenologia de plantas, sua interpretação e representação. Revista Brasileira Botânica 25: 269-275.

Castro QDV, Roldan LA. 2001. The Fate of Attalea phalerata (Palmae) seeds dispersed to a tapir latrine. Biotropica 33: 472-477

Costa CJ, Marchi ECS. 2008. Germinação de sementes de palmeiras com potencial para produção de agroenergia. Planaltina/Brasília , Embrapa Cerrados.

Fisch VTS, Nogueira Jr RL, Mantovani W. 2000. Fenologia reprodutiva de Euterpe edulis Mart. na Mata Atlântica (Reserva Ecológica do Trabiju Pindamonhangaba- SP).Revista Biociências 6: 31-37.

Francisco MR, Oliveira V, Galetti M. 2003. Massive seed predation of Pseudobombax grandiflorum (Bombacaceae) by parakeets Brotogeris versicolurus (Psittacidae) in a forest fragment in Brazil. Biotropica 34: 613-615

Garcia AH, Rosa JAM, Costa MGG. 1980. Contribuição ao conhecimento ao ataque do Pachymerus nucleurum Fabr. 1792 (Bruchidae: Coleoptera) em Syagrus oleracea Mart. (Palmae). Anais Escola Agronomia Veterinária 10: 5-11.

Grenha V, Macedo MV, Monteiro RF. 2008. Predação de sementes de Allagoptera arenaria (Gomes) O'K (Arecaceae) por Pachymerus nucleorum Fabricius (Coleoptera, Chrysomelidae, Bruchinae). Revista Brasileira Entomologia 52: 50-56.

Guedes ML, Ferreira PHG, Santana KNO, Pimenta MAS, Ribeiro LM. 2015. Fruit Morphology and Productivity of Babassu Palms in Northern Minas Gerais State. Revista Árvore 39: 883-892.

Guix JC. 2006. Complex plant-disperser-pest interactions in NW Amazonia: beetle larvae and companions travelling inside Attalea maripa palm nuts. Orsis 21: 83-90.

IGA - Instituto de Geociências Aplicadas. 2006. Áreas de Proteção Ambiental do Estado de Minas Gerais: demarcação e estudos para prézoneamento ecológico - EPA Bacia do Rio Pandeiros. Belo Horizonte, Governo do Estado de Minas Gerais.

INMET - Instituto Nacional de Meteorologia. 2012. http://www.inmet. gov.br. 10 May. 2012.

Janzen D H. 1971. The fate of Scheelea rostrata fruits beneath the parent tree: predispersal attack by bruchids. Principes 15: 89-101.

Janzen D H.1980. Specificity of seed-attacking beetles in a Costa Rican deciduous forest. Journal of Ecology 68: 929-952.

Jardim GAM, Kageyama YP. 1994. Fenologia de floração e frutificação em população natural de açaizeiro (Euterpe oleracea Mart.) no estuário amazônico. IPEF - Instituto de Pesquisas e Estudos Florestais 47: 62-65.

Johnson CD, Zona S, Nilson JA. 1995. Bruchid beetles and palm seeds: recorded relationships. Principes 39: 25-35.

Kaye TN, Liston A, Love RM, Louma DL, Meinke RJ, Wilson MV. 1997. Conservation and management of native plants and fungi. Corvallis, Native Plant Society of Oregon.

Kolb A, Ehrlén J, Eriksson O. 2007. Ecological and evolutionary consequences of spatial and temporal variation in pre-dispersal seed predation. Science Direct 9: 79-100.

Labouriau LG, Agudo M. 1987. On the physiology of seed germination in Salvia hispanica L. I. Temperature effects. Anais Academia Brasileira Ciências 59: 37-56.

Lima JRO, Silva RB, Silva CCM, Santos LSS, Santos-Jr. JR, Moura EM, Moura CVR. 2007. Biodiesel de Babaçu (Orbignya sp.) obtido por via etanólica. Química Nova 30: 600-603.
Lin SS. 1988. Efeito do tamanho e maturidade sobre a viabilidade, germinação e vigor do fruto de palmiteiro. Revista Brasileira Sementes 8: $57-66$

Lorenzi H, Souza HM, Madeiros-Costa JT, Cerqueira LSC, VonBehr N. 1996. Palmeiras no Brasil: exóticas e nativas. Nova Odessa, Plantarum.

Lorenzi H, Noblick L, Kahn F, Ferreira E. 2010. Flora Brasileira: Arecaceae (palmeira). Nova Odessa, Plantarum.

Martini A, Biondo D, Batista CA. 2011. Fenologia de Tabebuia chrysotricha (ipê-amarelo) no ambiente urbano de curitiba (PR). Revista da Sociedade Brasileira de Arborização Urbana 6: 51-67.

Matos FS, Nunes YRF, Silva MAP, Oliveira IS. 2014. Variação biométrica de diásporos de buriti (Mauritia flexuosa L.f. - Arecaceae) em veredas em diferentes estágios de conservação. Ciência Florestal 24: 833-842.

Narain N, Bora PS. 1992. Post-harvest changes in volatile flavour constituents of yellow passion fruit (Passiflora edulis f. Flavicarpa). Journal of the Science of Food and Agriculture 60: 529-530.

Neves SC, Ribeiro LM, Cunha I RG, Pimenta MAS, Mercadante-Simões MO, Lopes PSN. 2013. Diaspore structure and germination ecophysiology of the babassu palm (Attalea vitrivir). Flora (Jena) 208: 68-78.

Nunes YRF, Azevedo IFP, Neves WV, Veloso MDM, Souza RA, Fernandes GW. 2009. Pandeiros: o Pantanal Mineiro. Biota 2: 4-17.

Panza V, Lainez V, Maldonado S, Maroder S. 2007. Effects of desiccation on Euterpe edulis Martius seeds. Biocell 31: 383-390.

Ramirez N, Traveset A. 2010. Predispersal seed-predation by insects in the Venezuelan Central Plain: Overall patterns and traits that influence its biology and taxonomic groups. Perspectives in Plant Ecology, Evolution and Systematics 12: 193-209.

R Development Core Team. 2011. R: A language and environment for statistical computing. Viena, Austria: R foundation for Statiscal Computing. ISBN 3-900051-07-0. http://www.R-project.org. 06 Feb. 2012.

Sari LT, Ribeiro-Costa CS. 2005. Predação de Sementes de Senna multijuga (Rich.) H.S. Irwin \& Barneby (Caesalpinaceae) por Bruquíneos (Coleoptera: Chrysomelidae).Neotropical Entomology 34: 521-525.

Scariot A. 1998. Seed dispersal and predation of the palm Acrocomia aculeata. Principes 42: 5-8.

Silva GM, Tabarelli M.2001.Seed dispersal, plant recruitment and spatial distribution of Bactris acanthocarpa Martius (Arecaceae) in a remnant of Atlantic forest in northeast Brazil. Acta Oecologica 22: 259-268.

Silvius MK, Fragoso VM. 2002. Pulp handling by vertebrate seed dispersers increases palm seed predation by bruchid beetles in the northern Amazon.Journal of Ecology 90: 1024-1032.

Simão E, Nakamura AT, Takaki M. 2013. Germination of Styrax camporum Pohl. seeds in response to substrate types, moisture contents and the seed morphology. Anais Academia Brasileira de Ciências 85: 295-306.

Souza SCA, Braga LL, Tolentino SG, Matos MMA, Rodrigues SMP, Nunes YRF. 2007. Biometria de frutos e predação de sementes de Senna spectabilis (DC) Irwin et Barn. (Fabaceae-Caesalpinioideae) provenientes de três localidades do Norte de Minas Gerais.Revista Brasileira Biociências 5: 864-866.

Storti FE. 1993. Biologia Floral de Mauritia flexuosa Lin. Fin, na região de Manaus, AM, Brasil. Acta Amazonica 23: 371-381.

Vasconcelos JM, Rodrigues MA, Filho VSC, Sales JF, Silva FG, Santana JG. 2011. Dormancy break in seeds of "quina" (Strychnos pseudoquina A. St.-Hil.). Revista Brasileira Plantas Medicinais 13: 507-511. 